\section{SANIBEL CONFERENCE}

The Sanibel Conference will be January 29-February 1, 1991, at the Sundial Beach Resort on Sanibel Island. The topic is Ion Activation and Dissociation, and is organized by Richard Caprioli and Robert Boyd. The registration is limited to 125 persons in order to keep the agenda informal. Additional information may be obtained from the Society Office.

\section{SHORT COURSES}

ASMS will sponsor five short courses on May 18 and 19,1991 , immediately preceding the annual conference in Nashville. A new course, offered this year only, is Advanced Interpretation of Mass Spectra, taught by Fred McLafferty and Frank Turecek. The following is a complete list of the shott courses:

Introduction to the Interpretation of Mass Spectra, organized by the Washington, DC, Mass Spectrometry Discussion Group

Advanced Interpretation of Mass Spectra, organized by Fred McLafferty and Frank Turecek

LC/MS, organized by Al Yergey and John Coutant

Fundamentals of Protein Analysis, organized by Barbara Larsen and Charles McEwen

GC/MS Methods in Drug Testing, organized by Rodger Foltz, Jack Henion, and John Cody

\section{9th ASMS CONFERENCE}

You will find more than country music in Nashville, Tennessee, the site of the 39th ASMS Conference, May $19-24,1991$. The conference will be located in the magnificent Opryland Hotel, one of the largest convention hotels in the United States. The program will include the following plenary lectures:

Coulomb Explosion Imaging of Molecules, by Elliott $P$. Kanter, Argonne National Laboratory

The Science of Global Change, by Daniel Lee Albritton, National Oceanic and Atmospheric Administration

Archaebacterial RNA and Life at $100^{\circ}$ (Some Like It Hot), by James A. McCloskey, Uniwersity of Utah

Computer Modeling of Proteins and Nucleic Acids, by Richard Feldmann, National Institutes of Health

Complete conference information may be obtained from the Society Office.
A highlight of the ASMS Conference will be the announcement of the 1991 winner of the ASMS Award for Distinguished Contribution to Mass Spectrometry, as well as the presentation of the ASMS Research Awards sponsored by Finnigan MAT and VG Instruments.

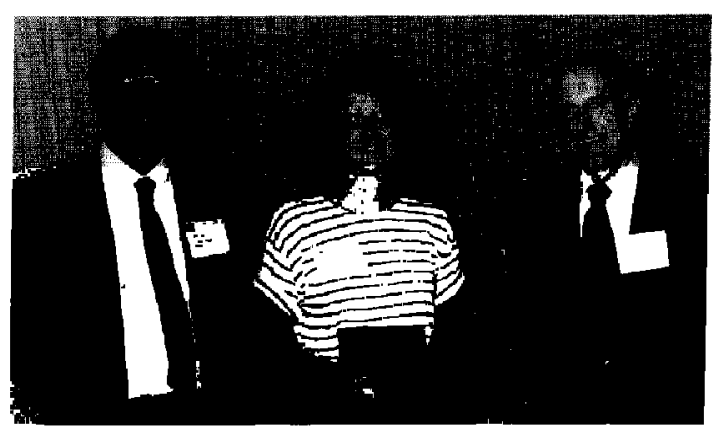

John Slayback, VG Instruments; Jennifer Brodbelt, 1990 recipient of an ASMS Research Award; and Robert Finnigan, Finnigan MAT. VG Instruments and Finnigan MAT sponsor the Research Awards.

\section{INTERNATIONAL CONFERENCE TRAVEL FUNDS}

ASMS and NSF have each contributed $\$ 10,000$ to fund travel to the 12th International Mass Spectrometry Conference, August 26-30, 1991, in Amsterdam. The funding is restricted to doctoral students and postdoctoral associates. The total of $\$ 20,000$ will be awarded on a competitive basis. Applications may be obtained from the Society Office.

\section{FUTURE ASMS CONFERENCES}

1991 May 19-24, Nashville, TN

1992 June 1-5, Washington, DC

1993 May 23-28, Las Vegas, NV

1994 May 29-June 2, Chicago, IL

1995 May 21-26, Atlanta, GA

1996 May 19-24, Anaheim, CA

\section{ASMS CALENDAR}

January 11

Deadline for conference abstracts Deadline for conference student travel stipend applications 
January 30 Deadline for travel awards for the 12th International Mass Specrometry Conference in Amsterdam

Jan. 29-Feb. 1 Sanibel Conference on Ion Activation and Dissociation

March

April 26

Conference Preliminary Program

Deadline for advance conference registration and short course registration

May 18-19

ASMS Short Courses

May 19-24

\section{ASMS MEMBER NEWS}

The following members have been honored for their achievements:

R. Graham Cooks

Ronald A. Hites

Ronald D. Macfarlane

Melvin B. Comisarow
1990 ACS Field and Franklin Award for Outstanding Achievement in Mass Spectrometry 1990 ACS Award for Creative Advances in Environmental Sciences and Technology

1990 ASMS Award for Distinguished Contribution to Mass Spectrometry 1989 Barringer Award of the Canadian Spectroscopy Society for development of FT-ICR

The ASMS News is prepared by Judith A. Watson, Executive Director. For additional information, contact ASMS, Post Office Box 1508, East Lansing, Michigan 48826; Telephone: (517) 337-2548.

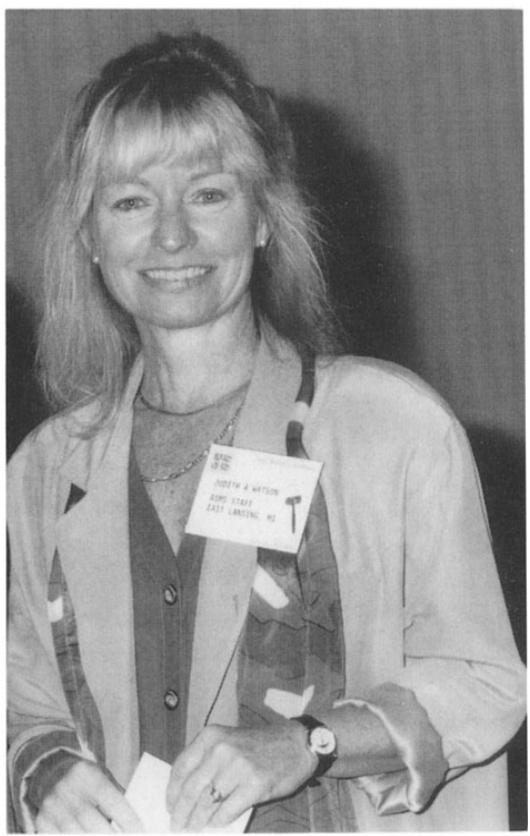

Judith Watson, Executive Director of ASMS

On the occasion of this 10th anniversary of the association of Judith Watson with the American Society for Mass Spectrometry, the Board of Directors, both past and present, would like to express their sincere gratitude to Judith for her dedication and service to our Society. The Society and attendees of each annual meeting have benefited greatly from her hard work and effort on our behalf.

Thank-you, Judith!

\section{CAPILLARY ELECTROPHORESIS, MICRO LIQUID CHROMATOGRAPHY, AND MASS SPECTROMETRY ANALYSIS OF PROTEINS AND PEPTIDES}

A seminar/workshop will be presented on March 2627, 1991, by the University of Nebraska-Lincoln Chemistry Department and Biotechnology Center, together with Isco, Inc. The seminar/workshop will be held in the Chemistry Department, University of NebraskaLincoln, Lincoln, Nebraska.

The workshop will include hands-on laboratory sessions in addition to lecture presentations by internationally recognized experts in biochemical applications of capillary electrophoresis, liquid chromatography, and mass spectrometry.

Contact Dr. Joseph Tehrani, Isco Inc., P.O. Box 5347, Lincoln, NE 68505, (402) 464-0231; for more information. 